\section{Biochemistry of Antibiotics}

THE first European symposium on "The Biochemistry of Antibiotics" was held during September 10-13, 1956, in Milan. The second volume of Giornale di Microbiologia (pp. 503, 1956) is devoted entirely to the papers given at this symposium and to the discussions which followed. The president, Prof. P. Rondoni, contributed the foreword, but unhappily he was not able to be present and he died shortly afterwards. The papers deal with topics such as the chemical composition and biosynthesis of antibiotics and their mode of action on pathogenic bacteria. There were thirty-four communications, most of them given in English; Sir Howard Florey, A. I. Virtanen and S. A. Waksman were among the contributors.

\section{Veszprém Polarographic Conference}

THE proceedings of the polarographic conference held in Veszprém, Hungary, in August 1955 have now been published in Acta Chimica (Hungary), 9 ; 1956. Forty-six papers were presented at this conference, covering general procedures, inorgenic, organic, biochemical and pharmaceutical applications of polarography. Among the subjects discussed were various new types of polarographic electrodes, oscillographic polarography and the use of kinetic currents for the determination of extremely high rates of reaction. The effect of maxima suppressors on the shape of polarograms was considered and an attempt was made to correlate the molecular weight of a suppressing agent with its concentration and maxima. suppressing ebility. Methods were described for the polarographic estimation of magnesium, gallium, oxygen, dithionite and various nitrogen-containing inorganic compounds. In the organic field the polarographic reduction of nitrogen-containing heterocyclic compounds, aromatic nitro-compounds, glucosazones and boric acid derivatives of $\mathrm{D}$-glucosazones were among the subjects studied. In the biochemical applications of polarography, investigations were reported on muscle proteins, proteins in serum obtained from liver lesions and mucoproteins in pneumoconiosis. Work on new methods of evaluation of catalytic protein waves was described, as also were researches on the Brdicka polarographic protein reaction. Various applications of polarography to pharmaceutical problems were recorded. Copies of the proceedings can be obtained from Kultura, Budapest VI, Magyar Ifjúság útja 21. Price 126 forints.

\section{Institute of Information Scientists}

A MEETing will be held on January 23, at 5.30 p.m., at the Institution of Electrical Engineers, Savoy Place, Victoria Embankment, London, W.C.2, to discuss terms of inauguration of an Institute of Information Scientists. The aims of the proposed Institute would include the promotion of high standards in scientific and technical information work, the promotion of educational courses, and the establishment of qualifications for those engaged in such information work. Membership of the Institute would be open, in the first place, to graduate (or similarly qualified) members of scientific, technical or economic information departments. Applications for admission tickets may be made to. J. Farradane, Torran, Crofton Road, Orpington, Kent. Applicants should indicate briefly their qualifications and enclose a stamped addressed envelope for reply.
University News :

Belfast

DR. D. T. Elmone has been appointed to a lectureship in biochemistry.

London

Prof. H. Lionel Elvin has been appointed director of the University of London Institute of Education from October 1, 1958. Since April 1956 Prof. Elvin has held the chair of education with special reference to education in tropical areas at the Institute. The title of reader in chemistry in the University of London has been conferred on Dr. C. A. Bunton and on Dr. A. Wassermann in respect of their posts at University College; and that of reader in applied mathematics in the University of London on Dr. E. P. Wohlfarth in respect of his post at the Imperial College of Science and Technology.

Melbourne

Dr. J. A. Patrman has been appointed a senior lecturer in botany.

Sheffield

THw Shell Petroleum Co., Ltd., has made a gift of $£ 15,000$ to the Development Fund of the University.

\section{Announcements}

Medals of the Tokyo Geographical Society have been awarded to Prof. L. Dudley Stamp, immediate past president, and Prof. Hans Ahlmann, president of the International Geographical Union.

Mr. LeONARd Rotherham, director of research and development at the Industrial Group Headquarters of the United Kingdom Atomic Energy Authority, Risley, Warrington, Lancs., has been appointed a full-time member of the Central Electricity Generating Board with effect from April 1.

The Institute of Personnel Management is holding a five-day residential study course in "The Employment Function of Management" during January 26-31 at the Prince of Wales Hotel, De Vere Gardens, Kensington, London, W.8. Further information can be obtained from the Courses Secretary, Institute of Personnel Management, Management House, 80 Fetter Lane, London, E.C.4.

A CoURSE in "The Use of Statistics in Personnel Management", organized by the Institute of Personnel Management in conjunction with the National Institute of Industrial Psychology, will be held nonresidentially at the National Institute of Industrial Psychology, 14 Welbeck Street, London, W.1, during January 20-24. It is intended for those personnel officers and managers who have had no previous training in the use of statistical methods and their application to personnel administration. Further information can be obtained from the Training Officer, Institute of Personnel Management, Management House, 80 Fetter Lane, London, E.C.4.

The British Institute of Management is holding a work study conference on February 6 . The fee for attendance is 7 guiness, which includes morning coffee, buffet luncheon and afternoon tea. The conference will be held in the Caxton Hall, Caxton Street, Victoria Street, London, S.W.1. Further information can be obtained from the British Institute of Management, Management House, 80 Fetter Lane, London, E.C.4. 